\title{
PROBLEMATIKA PERS LOKAL DALAM MENGHADAPI KONTESTASI PEMILIHAN KEPALA DAERAH (PILKADA) DI PROVINSI SUMATERA BARAT
}

\author{
Icol Dianto \\ Fakultas Dakwah dan Ilmu Komunikasi IAIN Padangsidimpuan \\ icoldianto@gmail.com
}

\begin{abstract}
$L$ ocal press problems in facing the contestation of the election of Regional Heads in West Sumatra Province can be grouped into two broad lines: first, the local press is dragged into a conflict of interest in the election of the Regional Head including 1) The Press supports one candidate pair, 2). Incitement of the success team, 3). The interests of media owners and stakeholders in media companies. Second, the intervention of the Regional Head towards local media includes 1). Change the Regional Head changes journalists, 2). Contract termination threats and 3). Media blockade. As for the solution to the problem, an alternative solution can be proposed that: 1). Re-guided Law Number 40 of 1999 concerning Press. 2). Balancing the press as a business industry with the press as a professional institution (social control). 3). The media owner should not use and manipulate his press company into the realm of practical politics. 5). In establishing cooperation with local governments, strive to stick to the principles and ethics of the journalistic profession. 6). Journalists must increase the capacity and quality of journalistic products, adhere to journalists' code of ethics, and not bring the profession into the realm of practical politics. 7). Report regional heads or parties who attempt to intimidate the media and journalists in carrying out their profession, to the Public Information Commission (KIP), police and Ombudsman at certain levels of government.
\end{abstract}

Keywords: Local Press, Problems, Pemilukada Contestation.

\begin{abstract}
ABSTRAK
$\mathrm{P}$ roblematika pers lokal dalam menghadapi kontestasi pemilihan Kepala Daerah di Provinsi Sumatera Barat dapat dikelompokkan pada dua garis besar: yaitu pertama, pers lokal terseret dalam konflik kepentingan pemilihan Kepala Daerah meliputi 1) Pers mendukung salah satu pasangan calon, 2). hasutan tim sukses, 3). kepentingan pemilik media dan pemangku kewenangan pada perusahaan media. Kedua, intervensi Kepala daerah terhadap media lokal meliputi 1). berganti Kepala Daerah berganti wartawan, 2). ancaman putus kontrak dan 3). blokade media. Adapun solusi untuk permasalahan tersebut, dapat diajukan alternative penyelesaiannya bahwa: 1). Mempedomani kembali UndangUndang Nomor 40 tahun 1999 tentang Pers. 2). Menyeimbangkan antara pers sebagai industry bisnis dengan pers sebagai lembaga professional (control social). 3). Pemilik media jangan memanfaatkan dan memperalat perusahaan pers miliknya ke ranah politik praktis. 5). Dalam menjalin kerja sama dengan pemerintah daerah, upayakan tetap berpegang pada prinsip dan etika profesi jurnalistik. 6). Wartawan mesti meningkatkan kapasitas dan kualitas produk jurnalistiknya, menaati kode etik wartawan, dan tidak membawa profesi ke ranah politik praktis. 7). Melaporkan kepala daerah atau pihak-pihak yang berupaya mengintimidasi media dan wartawan dalam menjalankan profesinya, ke Komisi Informasi Publik (KIP), polisi dan ombusman pada level pemerintahan tertentu.
\end{abstract}

Kata kunci: Pers Lokal, Problematika, Kontestasi Pemilukada.

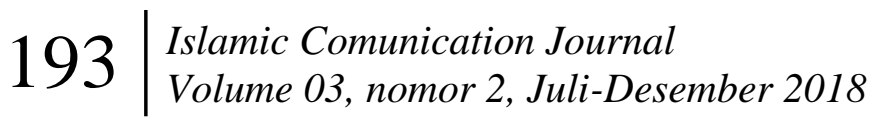




\section{PENDAHULUAN}

Pers sebagai salah satu pilar demokrasi yang memiliki kebebasan akses informasi telah menciptakan suatu tingkatan kondisi kekuatan pers. Iswandi Syahputra (Syahputra, 2013: xvii) menyebut kondisi pers di era demokrasi ini telah memasuki rezim media yang menguasai segala aspek kehidupan manusia. Masa ini dikenal dengan rezim media, meminjam istilah yang dipopulerkan oleh Bruce A. Williams dan Michael X Delli Carpini dengan buku berjudul After Broadcast News, Media Regimes, Democracy, And The New Information Environment. Pada rezim media, tidak hanya publik yang dikendalikan melainkan wacana kebijakan pemerintahpun dapat dipengaruhi. Hal ini sejalan dengan fungsi pers sebagai kontrol sosial sebagaimana terdapat dalam Bab II Asas, Fungsi, Hak, Kewajiban dan Peranan Pers Pasal 3 Undang-Undang Pers Nomor 40 Tahun 1999 tentang Pers. Akan tetapi, penyalahgunaan kebebasan menyampaikan informasi di era demokrasi telah membentuk budaya pers yang bebas tanpa kendali.

Kondisi bekuasanya pers (rezim media) ternyata tidak begitu terasa di lembaga pers lokal. Pers lokal dengan jangkauan pembaca terbatas sehingga kekuatannyapun terbatas. Keterbatasan pers lokal yang demikian itu seringkali mendapatkan ancaman dan dimanfaatkan oleh penguasa, kepala daerah dan instansi lainnya, untuk melakukan penekanan (intervention) terhadap perusahaan pers. Syahnan Harahap menemukan empat tindakan menyimpang terhadap kebebasan pers yaitu (1) distorsi melalui peraturan perundang- undangan yang dapat menyeret wartawan masuk penjara, (2) "budaya telepon" oleh birokrasi atau pemerintah, (3) tindakan "main hakim sendiri" oleh masyarakat, dan (4) dari kalangan pers itu sendiri. (Harahap, 2013: 27-28).

Kondisi pers lokal yang demikian itu terjadi hampir di seluruh wilayah Indonesia. Beberapa kasus kekerasan terhadap wartawan yang terjadi di Sumatera Barat, merupakan bentuk nyata ancaman terhadap kebebasan pers di tingkat lokal. Lembaga Bantuan Hukum (LBH) Pers dalam situs Kompas (Pers, 2017) mencatat peningkatan tindak kekerasan terhadap jurnalis pada 2016 sebanyak 83 kasus sedangkan pada tahun 2015 hanya 47 kasus. Kasus-kasus wartawan yang dipecat karena lalai dalam melaksanakan tugas yang "dipesan" oleh pemilik media, belum mencuat ke ruang publik. Demikian juga dengan kasuskasus yang berhubungan dengan penguasa yang berujung pada laporan polisi. Misalkan, kasus Fauzi Bahar melaporkan Koran Padang (media lokal) berawal dari pemberitaan Koran Padang yang menyudutkan Fauzi Bahar sebagai Wali Kota Padang. Pada waktu itu, Fauzi Bahar adalah bakal calon Gubernur Sumatera Barat. Kasus Bhenz Maharadjo, Wartawan Haluan, yang dilaporkan ke polisi oleh Gubernur Sumatera Barat Irwan Prayitno atas dugaan pencemaran nama baik dan penyebar berita bohong. Kedua kasus di atas adalah buntut panjang dari pemberitaan media yang ada hubungannya dengan pemilihan kepala daerah.

Selain itu, fenomena menjamurnya media cetak lokal yang terbit secara

\section{Islamic Comunication Journal


musiman, yaitu musim pemilihan kepala daerah saja. Media ini menawarkan publikasi kepada pasangan calon kepala daerah, dengan harga lebih mahal dari media selevelnya, namun bersedia memuat informasi tanpa batas, termasuk mengumbar ke ruang publik tentang kejelekan-kejelekan pasangan calon. Pada tahap ini, media dijadikan alat untuk melakukan kampanye hitam (black campign). Kondisi ini berdampak hampir pada semua media lokal, ada yang ingin menjelaskan informasi murahan itu. Ada juga yang berupaya untuk membangun good image dengan menggunakan kekuatan publikasi media massa. Politik pencitraan paling ampuh dilakukan lewat media koran dan media sosial. Akibatnya, media massa terlibat aktif dalam huruhara politik praktis. Inilah di antara beberapa persoalan yang hendak penulis jelaskan dalam tulisan ini, yang dirumuskan dengan judul, "Problematika Pers Lokal dalam Menghadapi Kontestasi Pemilihan Kepala Daerah (Pilkada) di Provinsi Sumatera Barat".

\section{SEJARAH PERKEMBANGAN PERS DI SUMATERA BARAT}

Suf Kasman (Kasman, 2010: 67-68) menyebut bahwa sejarah pers di Indonesia menjadi perdebatan panjang dua kelompok, termasuk perbedaan di kalangan wartawan sendiri. Perbedaan pendapat ini, kata Kasman, mengutip apa yang disampaikan Azyumardi Azra, bahwa perbedaan itu tidak bisa dilepaskan dari sudut pandang, data yang ditemukan, dan interpretasi terhadap data peneliti itu sendiri. Di samping kurangnya data yang dapat mendukung suatu teori dan sifat sepihak dari teori yang ada. Perbedaan pendapat itupun, kata Bung Karno seperti dikutip Kasman, akibat dari sikap tokohtokoh pers Indonesia yang kurang bahkan tidak memiliki pengertian perlunya penulisan sejarah. Karena kurangnya rujukan sumber dalam penulisan sejarah pers di Indonesia, maka menimbulkan berbagai teori yang dicetuskan oleh orang asing dalam persoalan sejarah ini.

Edward Cecil Smith lewat tesisnya A History of Newspaper Suppremassion in Indonesia, 1949-1965, mengatakan bahwa surat kabar yang pertama di Indonesia terbit setelah belanda mendarat di Hindia pada tahun 1596, lalu 19 tahun kemudian barulah mereka memulai menerbitkan sebuah medium komunikasi berupa penerbitan berkala bernama Gazette, 1516. Sementara, Yasuo Hanazaki dalam tesisnya The Indonesian Pres in the Era of Keterbukaan: A Force for Democration menyebutkan kelahiran pertama pers di Indonesia adalah bataviasche nouvelles en politique raisonnementen yang terbit pada agustus 1744 di Batavia. Pakar pers lain menyebutkan, pers yang pertama kali muncul adalah Medan Priyayi pada 1909. Kelahiran medan priyayi ini merupakan pers bumi putra pertama yang dieditori oleh orang pribumi adalah suatu bentuk perlawanan kalangan pribumi di Hindia Belanda, yang menjadikan pers sebagai corong perlawanan terhadap Pemerintah Kolonial Belanda. Sementara yang lain mengklaim yang disebut pers Indonesia setelah masyarakat Indonesia menikmati hari kemerdekaannya pada tanggal 17 Agustus 1945.

Kasman mengemukakan data bersumber dari proyek pusat publikasi pemerintah Departemen Penerangan RI, 
surat kabar Indonesia pada tiga zaman, menyebutkan bahwa di Padang, kini menjadi ibukota Provinsi Sumatera Barat, telah terbitnya surat kabar yang dikelola oleh pihak Belanda; Sumatra Courant, Padangsch Nieuws Advertientieblad dan Padangcsh Handelssblad dan pribumi; Bentara Melajoe. Berbagai periodisasi pers di Indonesia, menurut Kasman dapat dibedakan atas dua periode saja, pertama, semakin bebasnya pers dari kontrol Negara hingga tahun 1957 dan kedua, semakin luasnya kontrol Negara terhadap pers yang membuat pers menciut nyalinya (Kasman, 2010: 74). Haluan yang terbit sejak tahun 1948, merupakan media massa yang timbul karena adanya semangat baru usai kemerdekaan RI, yang pada masa ini dikenal dengan periodisasi partisan. Pada masa ini bermunculnya media-media lokal yang mengangkat idiologi dan perjuangan bangsa Indonesia.

Menurut Nasrul Azwar, aktivis budaya Sumatera Barat menyebutkan sepanjang pembacaan dia terhadap sejarah pers, dan juga hasil bacaannya terhadap disertasi Sudarmoko yang dipertahankannya di Universitas Leiden, Belanda (2005) dan beberapa artikel Suryadi yang juga mengajar di Universitas Leiden, mengesankan, semenjak abad-19, pertumbuhan surat kabar dan dunia penerbitan di Minangkabau (Sumatra Barat) sangat signifikan. Menurut Suryadi (2004) orang Padang bukan kemarin sore mulai membaca koran. Sejak 7 Desember 1864 hampir satu setengah abad lalu orang Minang untuk pertama kalinya membaca surat kabar berbahasa Melayu. Pada bulan itu, edisi perdana Bintang Timoer diluncurkan. Itulah koran pribumi pertama (vernacular press) yang terbit di kota Rumah Gadang itu. Minangkabau memang merupakan kota pers tertua di Sumatera, dan termasuk kota Indonesia yang awal mengenal surat kabar. Karena mendapat respons dan pasar yang baik, maka manajemen Bintang Timoer menerbitkan menjadi mingguan setiap Rabu yang dimulai sejak 4 Januari 1865.

"Ketika di tempat lain di pulau ini
orang baru mengenal naskah
(manuscript) beraksara Jawi yang
berisi sastra pagan, di Padang orang
(Minangkabau) sudah membolak-
balik halaman kertas lebar bernama
surat kabar yang berisi informasi dari
luar dunia lokalnya," tulis Suryadi
(lihat di www.ranah-minang.com).
Sejumlah surat kabar yang terbit di
Minangkabau setelah Bintang Timoer
antara lain, Pelita Ketjil (Padang,
1892-1894), Warta Berita (Padang,
1895), Tjahja Sumatra (Padang,
1906).

Tokoh pers yang menonjol saat itu antara lain, Mahyoeddin Datoek Soetan Maharadja, anak nagari Sulit Air, Abisin Abbas, Dja Endar Muda, dan Syekh Achmad Chatib. Tokoh pers itu hadir mewarnai dinamika pemikiran, arah kebijakan publik, dan dunia keintelektualan. Khairul Jasmi (Pantau, Februari 2002) menulis, saat itu, kepiawaian menulis atau mengeluarkan pendapat orang Minangkabau berpendaran di halaman-halaman surat kabar. Media massa jadi sarana melancarkan perbincangan dan polemik. Mula-mula tentang kebangkitan Asia, Jepang, lalu format masa depan negara. Tak luput juga tentang bagaimana agama Islam

\section{Islamic Comunication Journal


seharusnya dipahami dan dijalankan. Pesertanya kaum tua dan muda. Perdebatan agama inilah yang malah berlangsung tajam.

Demikian bagusnya kondisi pers saat itu, surat kabar Pelita Ketjil mampu menempatkan seorang korespondennya di Kota Mekkah, yang tugasnya mengirimkan berita perkembangan Islam untuk pembacanya di Sumatra Barat. Hal serupa tidak lagi kita temukan dalam manejemen surat kabar sekarang. Berita dari luar cukup dikutip dari kantor-kantor berita yang bertebaran itu. Selain koran mainstream di atas, seperti Bintang Timoer, Pelita Ketjil, Warta Berita, Tjahja Sumatra dan lain sebagainya, di tingkat nagari dan etnis juga muncul berbagai penerbitan berkala. Media komunitas hadir dikesankan sebagai ruang komunikasi dan silaturahmi bagi masyarakatnya. Dalam catatan Sudarmoko (2005) beberapa penerbitan "pers" komunitas saat antara lain, Barito Koto Gadang (Fort de Kock, 1929-32), Boedi Tjaniago (Fort de Kock, Drukkery Agam, 1922), Soeara Kota Gedang (Fort de Kock, Vereeniging Studiefonds Kota Gedang, 1916-17), Al Achbar (Padang, 1913-14, dalam bahasa Arab), Al I'laam (Koto Toeo, Ampat Angkat, 1922-23), Moeslim India (Padang, Moeslim India, 1932), Algementeen Advertieblad (Padang, Padangsche Snelpres, 1921, dalam bahasa Belanda), Bintang Tiong Hoa (Padang, Tiong Hoa Ien Soe Kiok, 1910-15).

\section{METODE ANALISIS}

Paper ini merupakan hasil penelitian dengan menggunakan metode studi kasus terhadap persoalan pers terbitan Sumatera
Barat. Subjek penelitian adalah pelaku jurnalistik, meliputi wartawan, dan manajemen usaha media pers. Studi Kasus (Sugiyono, 2017: 17) merupakan jenis penelitian kualitatif yang mana peneliti melakukan eksplorasi secara mendalam terhadap program, kejadian, proses, aktivitas terhadap satu atau lebih orang. Menurut Kriyantono, metode studi kasus adalah metode riset yang menggunakan berbagai sumber data (sebanyak mungkin), yang bisa digunakan untuk meneliti, menguraikan, dan menjelaskan secara komprehensif berbagai aspek individu, kelompok, suatu program, organisasi, atau peristiwa secara sistematis (Kriyantono, 2007: 66).

\section{PROBLEMATIKA PERS LOKAL} DALAM MENGHADAPI SITUASI PEMILIHAN KEPADA DAERAH DI PROVINSI SUMATERA BARAT

\section{Pers Lokal Terseret Dalam Konflik}

\section{Kepentingan Pilkada}

Kekuatan pers sebagai media kontrol dan kritik sosial sudah tidak diragukan lagi. Ia lantang menyuarakan suara rakyat dalam berekspresi mengeluarkan pendapat dan aspirasi. Pers dalam hal ini sebagai wadah untuk mengungkapkan suara-suara keadilan dari rakyat. Kekuatan pers sebagaimana merupakan asas layak berita pada perusahaan pers yang bebas dan bertanggungjawab, aktual dan berimbang. Kebebasan ini yang pada perjalanan sejarah pers Indonesia telah dimanfaatkan oleh pemilik modal. Banyak perusahaan pers yang dikuasai oleh konglomerat dan politikus hartawan. Pers sebagai kontrol dan kritik sosial mengalami pergeseran hak dan kewajiban ke arah politik praktis, 
sarana untuk mendapatkan kekuatan dan kekuasaan. Kondisi ini yang kemudian menyeret pers ke dalam kepentingan politik praktis.

Di Indonesia, pesmirsa tidak asing lagi dengan media televisi TV One milik Abu Rizal Bakrie (Ical) mantan Ketua Umum Partai Golongan Karya, Metro TV milik Surya Paloh Ketua Umum Partai NasDem, MNC Group milik Hari Tanoe Sudibyo, Ketua Umum Partai Perindo. Fakta-fakta ini juga merembes ke media lokal yang terbit di sejumlah provinsiprovinsi di Negeri ini. Misalkan saja di Provinsi Sumatera Barat, ada media Harian Umum Haluan yang merupakan milik almarhum Kusumah dan keluarga, yang kemudian melibatkan diri sebagai politikus dan menjabat pada lembaga legislatif di wilayah Sumatera Barat tingkat I dan II. Setelah itu, Harian Umum Haluan diambilalih oleh Basrizal Koto (Basko) seorang pengusaha sukses asal Sumatera Barat yang kemudian aktif mendukung pasangan calon kepala daerah di provinsi riau, kepulauan riau dan sumatera barat. Kemudian ada Koran Singgalang, milik Basril Djabar yang kemudian terjun ke dunia politik di kancah Nasional, yakni sebagai anggota DPR RI.

Dari analisis penulis terhadap persoalan ini, selain kepemilikan media massa oleh politikus atau dari praktisi media menerjunkan diri ke politik praktis, ada faktor lain yang menjadikan pers terlibat dalam politik praktis. Faktor yang dimaksud adalah faktor kepentingan omset perusahaan. Kewajiban operasional perusahaan media, mengharuskan aktoraktor media memanfaatkan semua momen untuk mendapatkan omset perusahaan yang sebesar-besarnya. Fenomena ini termasuk momen pemilihan kepala daerah. Pesta demokrasi yang digelar sekali lima tahun itu merupakan momen besar oleh perusahaan pers untuk meraup capaian omset yang tinggi. Aneka ragam strategi oleh pemimpin perusahaan pers untuk mewujudkan capaian omset itu. Upaya lobi ke pasangan calon dengan membuat kontrak publikasipun dilakukan. Semakin banyak pasangan calon kepala daerah maka semakin tinggi kesempatan untuk meraup omset. Akan tetapi, fakta menyatakan bahwa tidak semua pasangan calon sanggup untuk membuat kontrak publikasi dengan media massa. Apalagi nilai kontrak yang cukup tinggi untuk satu media massa. Pada pemilihan kepala daerah serentak di Provinsi Sumatera Barat tahun 2014, nilai kontrak satu media harian dengan satu pasangan calon mencapai Rp.100.000.000,- (seratus juta rupiah) (Ramadian, 2015). Mahalnya nilai publikasi menyebabkan hanya pasangan calon yang sanggup saja yang mampu membuat kesepakatan dengan media massa.

Imbas dari kondisi ini, menjadikan media massa terikat kontrak untuk memperbanyak publikasi pasangan calon yang menjalin kerja sama, dan mengabaikan publikasi untuk pasangan calon yang tidak membuat kontrak. Hal ini tentu saja wajar dalam dunia bisnis media, namun sebetulnya dapat saja menyalahi aturan-aturan dalam pemilihan kepala daerah. Lembaga pengawas pemilihan umum dapat saja menilai suatu media massa itu tidak netral, dan mendukung salah satu pasangan calon.

\section{Islamic Comunication Journal


Padahal di balik apa yang diamati dari publikasi itu, sesungguhnya ada kontrak publikasi yang mengikat antara perusahaan media dengan pasangan calon tertentu.

Hal itu dilakukan oleh pengelola media massa, karena untuk penyelenggaraan penerbitan media massa itu memerlukan biaya lumayan besar. Menutupi biaya tersebut, sewajarnya pihak media turut memanfaatkan momentum pilkada itu untuk meraup omset yang besar. Moentadhim (Moentadhim, 2006:309) menyebutkan bahwa biaya penerbitan dapat ditutupi oleh penghasilan iklan mencapai 60 persen. Iklan sebagai donator yang membuat pengelola media massa dapat bernafas lega, karena itu diperlukan tenaga periklanan yang handal.

a. Pers mendukung salah satu pasangan calon

Kontesasi pemilihan kepala daerah sudah tidak tabu lagi membicarakan persoalan siapa mendukung siapa. Dukungan itu merupakan hak politik warga Negara, kecuali profesi aparatur sipil Negara, TNI, Polri yang harus netral, namun kelompok profesi itu memiliki hak suara untuk memilih dan dipilih. Temuan penulis bahwa persoalan dukungan itupun terjadi pada media massa. Ada fenomena perseteruan media massa nasional dan lokal karena terlibat dalam posisi mendukung salah satu pasangan calon. Toh, kalaupun suatu media massa dituntut untuk memberitakan secara berimbang, namun pasangan calon yang tidak didukung oleh media massa akan mendapatkan porsi publikasi yang lebih kecil dibandingkan dengan pasangan calon yang didukung oleh pers tersebut.

Televisi wajib bersikap adil dan proporsional terhadap para peserta pemilu dan pilkada dan dilarang bersikap partisan terhadap salah satu peserta pemilu dan pilkada, sedangkan peserta pemilu dan pilkada dilarang membiayai atau mensponsori program yang ditayangkan stasiun televisi (Morissan, 2008: 258). Pendapat Morissan ini tentu juga berlaku bagi semua media massa, baik cetak maupun elektronik. Akan tetapi fakta di lapangan, banyak halaman Koran yang diboking oleh salah satu pasangan calon kepala daerah, untuk mempublikasikan kegiatan individu dan timnya dalam upaya membangun citra positif dari masyarakat pemilih.

Dukungan media massa terhadap pasangan calon selain dari kontrak publikasi, dan kepentingan pemilik media pers, merupakan dukungan yang diikat oleh faktor ideologi. Pada masyarakat modern, dukungan yang diikat oleh faktor ideologi menempati faktor utama. Ikatan ideologi bahkan melebihi dari ikatan persaudaraan sedarah. Pada beberapa fenomena dapat ditemukan bahwa ada tokoh bangsa yang bersaudara namun tidak saling mendukung dalam pemilihan kepala daerah dan pemilihan presiden. Hal itu wajar karena memang yang membentuk karakter manusia itu bukan karena hubungan persaudaraan namun karakter yang dibentuk pada tahap ideologi (mindset).

Keterlibatan owner/ pemilik media Harian Haluan, H. Basrizal Koto dalam mendukung salah satu pasangan calon Gubernur Sumatera Barat, yaitu pasangan 
Muslim Kasim - Fauzi Bahar, pada Pemilihan Gubernur dan Wakil Gubernur Sumatera Barat Periode 2015-2021, mendatangkan kesulitan-kesulitan bagi perusahaan pers. Kontrak Harian Haluan di kantor gubernur mendapatkan kendala, liputan khusus/ pariwara dikurangi. Gubernur menjabat, yang merupakan rival dari pasangan calon yang didukung media, menyampaikan kepada pejabat di lingkungan Pemerintahan Provinsi Sumatera Barat untuk tidak mempublikasikan pariwara dan iklan (berbayar) dengan Koran Harian Haluan. Di sisi lain, hal ini telah berdampak dengan mundurnya Pemimpin Redaksi Haluan Yon Erizon, karena ketidaksenangan owner media kepadanya atas manajemen pemberitaan pasangan calon gubernur yang diusung owner selama masa-masa kampanye berlangsung.

\section{b. Hasutan tim sukses}

Hasutan tim sukses seringkali menjadi faktor pemecah masyarakat pascapilkada. Tim sukses yang bagaikan pahlawan itu biasanya muncul dengan berbagai cerita heroik dalam memenangkan pasangan calon yang didukungnya. Ia seringkali menceritakan pengalaman tempurnya waktu kampanye untuk mengajak massa memilih jagoannya. Dalam mendramatisir cerita, acapkali tim sukses menerangkan pihakpihak lain yang menjadi lawannya di lapangan. Alhasil, cerita pada pihak yang menang, maka masyarakat seringkali mempercayai ucapan orang tersebut. Ada beberapa kelompok masyarakat dalam menanggapi cerita heroik tim sukses itu, yakni mempercayai ucapan tim sukses, pura-pura simpati dengan ucapan tim sukses dan tidak mempercayai sama sekali ucapan tim sukses itu.

Hasutan tim sukses ini tidak sedikit mengorbankan pihak-pihak tertentu yang dianggap lawan oleh tim sukses itu. Ini dikenal dengan luka pascapilkada. Korban dari hasutan tim sukses ini tidak hanya menyasar ke tim sukses pasangan calon lainnya, tetapi juga merembes ke media massa. Dalam persoalan ini, ada dua hal yang perlu jelaskan, yakni tim sukses versus awak media (jurnalis), dan awak media versus awak media. Pergulatan kepemimpinan pada momen pilkada memunculkan kekuatan baru yang juga imbasnya ke kekuasaan tingkat rendah. Setiap tingkatan jabatan dan profesi mempunyai lawan yang sebanding. Tukang sapu lawan tukang sapu, pejabat eselon lawan pejabat bereselon, dan demikian juga jurnalis lawannya juga jurnalis. Dalam hal ini, seringkali muncul wartawan-wartawan baru yang selama ini termarginirkan oleh kelompok wartawan yang lainnya. Apapun bentuk profesi dari tim sukses, maka mereka akan melancarkan sebuah propaganda melalui hasutan kepada pihak-pihak yang dianggap lawan.

c. Kepentingan pemilik media dan pemangku kewenangan pada perusahaan media

Pada dasarnya, manusia bertindak memiliki motif tertentu yang hendak dicapainya. Banyak kepentingan yang bertengger dalam tindakan itu. Ada motifnya untuk kekuasaaan, pratise, status sosial, dan seyogyanya motif dari setiap tindakan manusia itu adalah ikhlas karena

\section{Islamic Comunication Journal Volume 3, Nomor 2, Juli-Desember 2018


Allah (lillahi ta'ala). Dalam hal melanggengkan kekuasaan, seringkali orang berbuat brutal (kekerasan) dan ada dengan cara yang lebih bermartabat.

Purnama Suwardi (Suwardi, 2006: 2) menyebutkan bahwa kondisi saat ini siaran televisi dimanfaatkan banyak pihak sebagai sarana intervensi tidak langsung untuk membangun kebenaran-kebenaran sendiri. Beberapa pengusaha di Indonesia, untuk mendapatkan tujuan kekuasaaan, telah mengambil alih banyak media cetak, elektronik dan televisi. Pada kasus media massa, sudah menjadi dominasi di tanah air (Indonesia), owner media nasional dan lokal adalah memiliki ikatan sosial dengan partai politik atau ikut terlibat pada ranah politik praktis. Sebut saja Abu Rizal Bakrie, pria yang akrab disapa Ical ini merupakan pimpinan partai Golongan Karya (Golkar), Surya Paloh pimpinan partai NasDem memiliki Metro TV, Hari Tanoe Sudibjo dengan group MNC TV memiliki partai Partai Persatuan Indonesia (Perindo). Fakta ini yang dapat menyeret media massa ke ranah politik praktis. Ada program siaranan atau tayangan yang merupakan pesanan dari owner media massa itu sendiri. Terkadang pesanan bos media itu tidak sesuai dengan kode etik jurnalistik, namun program itu harus juga ditayangkan.

Perusahaan pers sudah memiliki subbagian yang memiliki kewajiban yang berbeda-beda, ada bidang keredaksian dan ada bidang usaha (bisnis). Untuk menerbitkan produk jurnalistik, meski kedua bidang itu saling bersinergis, namun soal produk jurnalistik menjadi tanggungjawab bidang keredaksian. Jadi, program siaran atau mungkin program liputan pada media cetak, menjadi tanggungjawab pemimpin redaksi untuk menerbitkannya. Berita yang dicari dan diolah oleh wartawan bisa jadi dimuat atau tidak dimuat karena berita itu ditolak dalam rapat pimpinan redaksi. Akan tetapi, berbeda dengan program siaran pesanan bos maka harus dimuat. Lebih baik tidak cetak atau tidak tayang daripada tidak menayangkan pesanan bos.

Menurut teorinya, untuk menerbitkan produk jurnalistik dapat dipengaruhi oleh banyak faktor, yakni tingkat individual, tingkat rutinitas media, tingkat organisasi, tingkat ekstra media, dan tingkat ideologi. Ideologi media terletak pada fungsi kontrol sosial yang dijalankan oleh perusahaan media. Ketidakberimbangan pemberitaan karena pesanan pemilik media (owner) seringkali merobek ideologi tersebut. Beberapa perusahaan pers harus bertentangan dengan opini publik demi menjalankan permintaan owner.

\section{Intervensi Kepala Daerah Terhadap Media Lokal}

Selama masa orde baru, pers di Indonesia terjebak pada konflik tiga kepentingan sekaligus, yaitu Negara, pemodal dan masyarakat. Negara menuntut pers menjadi agen pembangunan (agent of development), di sisi lain pemilik modal memaksa pers menjadi sebuah industri dengan logika perniagaan dan keuntungan, sedangkan masyarakat meminta pers untuk menjadi penyedia informasi yang aktual dan faktual serta menjalankan fungsi pemberdayaan dan kontrol sosial (Fatah, 1998: 194-195). 


\section{a. Berganti Kepala Daerah Berganti Wartawan}

Pergantian kepala daerah dan tim suksesnya pada saat kontestasi pemilihan kepala daerah berlangsung, memberikan dampak pada profesi wartawan. Perang ideologi, program dan kampanye politik yang dipublikasikan pada suatu media, merupakan peluang bisnis bagi media massa. Pemberitaan tentang pasangan calon kepala daerah ditunggu oleh masyarakat luas, baik kelompok pemesan release (pariwara dan liputan khusus), maupun pihak lawan dari pasangan calon lainnya. Kondisi ini berdampak ekonomis, karena halaman dibeli dengan label harga khusus, dan pembokingan edisi cetak. Pada tahap ini, dampak yang didapatkan oleh wartawan adalah hal yang positif, berupa peningkatan penghasilan.

Pada sisi lain, dampak yang negatif dapat diterima oleh wartawan ketika kontestasi pemilihan kepala daerah telah selesai. Akan ada pengelompokan wartawan pada tiga kategori, yaitu wartawan pendukung (koalisi), wartawan lawan (oposisi) dan wartawan yang professional (netral). Wartawan pendukung akan mendapatkan tempat utama di sisi kekuasaan kepala daerah, dekat dengan kepala daerah, pimpinan dinas, lembaga dan kantor yang masuk dalam struktur organisasi pemerintah daerah (OPD), termasuk bagian hubungan masyarakat (Humas) yang menjadi pintu masuk kerja sama media massa dengan pemerintah daerah. Publikasi terkait dengan kegitan kepala daerah, dan prestasi pemerintah daerah diperuntukkan secara istimewa untuk media massa yang dikendarai oleh wartawan pendukung.

Kepala Perwakilan Media Koran Post Metro di Pasaman, Rahmat Wahyudi (2018), menjelaskan bahwa wartawan yang dianggap lawan kepala daerah semasa kontestasi pemilihan kepala daerah berlangsung, di masa-masa kampanye, terindikasi wartawan banyak memberitakan prestasi calon kepala daerah yang lain. Bagi kelompok wartawan oposisi, mereka ada yang diganti. Kewenangan untuk mengangkat dan memberhentikan wartawan ada di tangan perusahaan media, namun di Sumatera Barat, dapat saja dipengaruhi oleh permintaan mitra kerja, seperti permintaan kabag humas, bupati dan wakil bupati pemenang kontestasi. Pihak manajemen media, karena menyelenggarakan perusahaan media tidak selesai dengan ideologi saja, melainkan memerlukan biaya yang cukup besar. Akibatnya, pihak manajemen lebih memilih mengganti, memindahkan dan bahkan memberhentikan wartawan yang tidak disenangi oleh kepala daerah tersebut.

Keprofesionalan wartawan pada tingkat lokal diukur dengan capaian omset. Mestinya wartawan professional itu diukur dengan standar profesi wartawan, yaitu yang dituangkan dalam kode etik wartawan Indonesia. Keprofesionalan wartawan itu mengandung pada kebenaran berita, kualitas berita, dan produktifitas wartawan dalam melahirkan produk-produk jurnalistik. Wartawan tipe ini selalu bias menyesuaikan diri dengan pihak-pihak yang terlibat dalam kontestasi pemilihan 
kepala daerah. Namun, fakta yang terjadi bahwa jika wartawan bertahan pada ideologi profesionalisme, maka wartawan tersebut biasanya hanya diagungkan pada level konseptual. Ia dijadikan model oleh kepala daerah dan pihak terkait, untuk dibanding-bandingkan dengan wartawan lainnya. Untuk omset dan kesejahteraan yang didapatkan oleh wartawan koalisi/pendukung jauh lebih tinggi, tidak akan pernah sebanding dengan apa yang didapatkan oleh wartawan professional.

\section{b. Ancaman Putus Kontrak}

Pers regional atau lokal meski juga memuat informasi internasional dan nasional, namun ia tidak dikategorikan dengan pers umum atau pers nasional. Pers lokal itu memiliki sirkulasi yang terbatas dan dana terbatas (Bland, 2001: 46). Putus kontrak termasuk dampak fatal yang didapatkan oleh wartawan dan perusahaan pers terkait kontestasi pemilihan kepala daerah ini. Apabila permintaan untuk mengganti wartawan yang diajukan oleh pihak kepala daerah tidak dikabulkan, maka bisa saja pihak pemerintah daerah melakukan putus kontrak. Putus kontrak akan berdampak pada penghasilan wartawan dan perusahaan pers. Pada perusahaan media yang mapan secara finansial, kontrak dengan pemerintah daerah tidak dipandang sesuatu yang urgen/penting. Mereka beranggapan bahwa kontrak kerja sama dengan pemerintah hanya akan menghambat pihak media untuk mempertahankan ideologi jurnalistik. Kontrak kerjasama adalah pintu masuk bagi kewenangan kepala daerah untuk ikut campur dalam pengelolaan pemberitaan media. Ancaman intervensi penguasa dapat menghantui kerja keprofesinalan perusahaan pers. Oleh karena itu, bagi perusahaan media yang sudah mapan finansial tidak begitu memperdulikan ada atau tidak jalinan hubungan kerjasama dengan kepala daerah.

Menurut Sayadiman (Sobur, 2001: 268) kurangnya kemandirian masyarakat Indonesia, termasuk dalam mengelolah bisnis pers, akibat dari sejarah bangsa yang telah lama dijajah oleh penguasa yang bersifat feodal. Membiasakan orang untuk bergantung pada pihak yang kuat atau berkuasa. Pada kondisi ini, bila ada suatu lembaga atau organisasi masyarakat yang terlihat mandiri, malah pihak penguasa memberikannya hukuman atas kesalahan tersebut, sehingga sikap mandiri, kreatif dan inovatif menjadi mandeg. Inilah yang terjadi pada perusahaan pers yang hidupnya media itu lebih banyak bergantung pada kontrak kerjasama dengan pemerintahan. Media pada kategori ini menganggap kontrak kerjasama dengan kepala daerah sangat penting. Kepala daerah menjadi target utama pencapaian omset perusahaan. Maka putus kontrak bagi perusahaan pers ini dianggap fatal dan membahayakan bagi stabilitas keuangan perusahaan. Tidak heran putus kontrak dengan humas dan kepala daerah sesuatu yang ditakuti dan dihindari oleh perusahaan media. Maryadi (2018) menjelaskan bahwa prinsip yang dipakai oleh pihak manajemen adalah biarlah membuang satu wartawan yang tidak disenangi kepala daerah, ketimbang menganiaya perusahaan yang bergantung hidup banyak karyawan padanya. Pihak manajemen media menganggap dengan putus kontrak 
dengan kepala daerah menjadikan pendapatan perusahaan berkurang, sehingga mempengaruhi penghasilan banyak karyawan administrasi dan percetakan di media tersebut. Anggapan itu tidaklah kebenaran mutlak. Penggajian karyawan perusahaan yang hanya di kantor saja, tentu diambilkan dari akumulasi pendapatan dari semua sumber keuangan perusahaan, bukan hanya dari satu kontrak kerjasama saja. Apalagi bagi karyawan yang turun langsung ke lapangan, seperti devisi iklan, wartawan dan pemimpin perusahaan, yang telah disediakan sumber-sumber penghasilannya baik oleh perusahaan sendiri maupun disediakan oleh mitra di lapangan (walaupun tidak diminta).

\section{c. Blokade Media}

Pemblokan media jarang terjadi, namun ada kasusnya menimpa beberapa media di Sumatera Barat. Pemblokan ini biasanya tidak lama, karena cepat diambil kebijakan oleh pihak media. Kondisi demikian itu bila dipertahankan lebih lama, hanya akan merugikan perusahaan pers. Seringkali penyelesaian dari konflik interest ini, pihak media dirugikan baik secara ideologi maupun materil. Bisa saja keharusan untuk taat dan patuh pada kekuasaan kepala daerah menjadi persyaratan dalam penyelesaian konflik ini. Pemilik media cetak mingguan Zaman, Irawadi (2017), menjelaskan bahwa media yang dipimpinnya sering mendapatkan ancaman putus kontrak dari pemerintah daerah. Penyebabnyapun beragam mulai dari pemberitaan yang tidak memihak pemerintahan, konten berita yang dianggap pro terhadap lawan politik kepala daerah, dan persoalan lain yang ada di bagian Humas. Kondisi itu tidak hanya Koran Mingguan Zaman yang pernah mengalami hal demikian. Koran Harian Singgalang, pernah diputuskontrak oleh Bupati Pasaman Barat Baharuddin R. Bahkan lebih hebohnya lagi, Pemerintah Kabupaten Solok diakhir masa pemerintahan Syamsu Rahim pernah mengambil kebijakan untuk tidak berlangganan Koran lagi. Tentu saja kondisi ini menjadi pukulan telak bagi pers lokal yang sebagian besar biaya operasionalnya bersumber dari nilai kontrak dengan pemerintah daerah.

\section{SOLUSI ATAS PROBLEMATIKA PERS LOKAL DALAM MENGHADAPI SITUASI PEMILIHAN KEPADA DAERAH DI PROVINSI SUMATERA BARAT}

Setiap ada masalah pasti ada jalan penyelesaiannya. Hanya saja cepat atau lambatnya masalah diselesaikan, tergantung pada kecepatan dan ketepatan tindakan dalam mencarikan solusinya. Tersedianya solusi-solusi dari berbagai sumber, menjadi alternative dalam menyelesaikan konflik serupa. Untuk masalah yang dibahas dalam artikel ini, "Problematika Pers Lokal Dalam Menghadapi Kontestasi Pemilihan Kepada Daerah di Provinsi Sumatera Barat, dapat diajukan alternatif penyelesaiannya sebagai berikut:

1. Mempedomani kembali UndangUndang Nomor 40 tahun 1999 tentang Pers.

2. Menyeimbangkan antara pers sebagai industri bisnis dengan pers sebagai lembaga professional (control social).

\section{Islamic Comunication Journal Volume 3, Nomor 2, Juli-Desember 2018


3. Pemilik media jangan memanfaatkan dan memperalat perusahaan pers miliknya ke ranah politik praktis.

4. Dalam menjalin kerja sama dengan pemerintah daerah, upayakan tetap berpegang pada prinsip dan etika profesi jurnalistik.

5. Wartawan mesti meningkatkan kapasitas dan kualitas produk jurnalistiknya, menaati kode etik wartawan, dan tidak membawa profesi ke ranah politik praktis.

6. Melaporkan kepala daerah atau pihak-pihak yang berupaya mengintimidasi media dan wartawan dalam menjalankan profesinya, ke Komisi Informasi Publik (KIP), polisi dan ombusman pada level pemerintahan tertentu.

\section{KESIMPULAN}

Pers sebagai salah satu pilar demokrasi yang memiliki kebebasan akses informasi telah menciptakan suatu tingkatan kondisi kekuatan pers. Pada rezim media, tidak hanya publik yang dikendalikan melainkan wacana kebijakan pemerintahpun dapat dipengaruhi oleh media. Kondisi bekuasanya pers (rezim media) ternyata tidak begitu terasa di lembaga pers lokal. Pers lokal dengan jangkauan ruang pembaca yang terbatas sehingga kekuatannyapun terbatas.

Problematika pers lokal dalam menghadapi kontestasi pemilihan Kepala Daerah di Provinsi Sumatera Barat dapat dikelompokkan pada dua garis besar: yaitu pertama, pers lokal terseret dalam kepentingan pemilihan Kepala Daerah meliputi kegiatan pers terkesan mendukung satu pasangan calon, hasutan tim sukses, kepentingan pemilik media dan pemangku kewenangan pada perusahaan media. Kedua, intervensi Kepala daerah terhadap media lokal meliputi kegiatan berganti Kepala Daerah berganti wartawan, ancaman putus kontrak dan blokade media.

Adapun solusi untuk permasalahan tersebut, dapat diajukan alternatif penyelesaiannya bahwa: 1). Mempedomani kembali Undang-Undang Nomor 40 tahun 1999 tentang Pers. 2). Menyeimbangkan antara pers sebagai industri bisnis dengan pers sebagai lembaga professional (control social). 3). Pemilik media jangan memanfaatkan dan memperalat perusahaan pers miliknya ke ranah politik praktis. 5). Dalam menjalin kerja sama dengan pemerintah daerah, upayakan tetap berpegang pada prinsip dan etika profesi jurnalistik. 6). Wartawan mesti meningkatkan kapasitas dan kualitas produk jurnalistiknya, menaati kode etik wartawan, dan tidak membawa profesi ke ranah politik praktis. 7). Melaporkan kepala daerah atau pihak-pihak yang berupaya mengintimidasi media dan wartawan dalam menjalankan profesinya, ke Komisi Informasi Publik (KIP), polisi dan ombusman pada level pemerintahan tertentu.

\section{DAFTAR PUSTAKA}

Bland, M. (2001). Hubungan Media Yang Efektif. (Syahrul, Ed.) (Translit). Jakarta: Penerbit Erlangga.

Fatah, E. S. (1998). Bangsa Saya Yang Menyebalkan: Catatan Tentang Kekuasaan Yang Pongah. Bandung: Remaja Rosdakarya.

\section{5 |l $\begin{aligned} & \text { Islamic Comunication Journal } \\ & \text { Volume 03, nomor 2, Juli-Desember } 2018\end{aligned}$}


Harahap, M. Syahnan, Tinjauan Hukum Peran Pers Guna Menegakean Hak Asasi Manusia Di Indonesia, Jurnal Ilmiah Hukum Dirgantara, Vol 4 No. 1 (2013).

Kasman, S. (2010). Pers dan Pencitraan Umat Islam di Indonesia: Analisis Isi Pemberitaan Harian Kompas dan Republika. Jakarta: Balai Litbang dan Diklat Kemenag RI.

Kriyantono, R. (2007). Metode Riset Komunikasi. Jakarta: Kencana.

Moentadhim, M. (2006). No Title. Yogyakarta: CV Andi Offset.

Morissan. (2008). Jurnalistik Televisi Mutakhir. Jakarta: Kencana.

Pers, L. (2017). Kasus Kekerasan Terhadap Pers 2016 Meningkat.

Ramadian, D. (2015). Kontrak Kerja Sama Haluan dengan Pasangan Calon Bupati dan Wakil Bupati se Sumatera Barat. Padang.

Sobur, A. (2001). Etika Pers: Profesionalisme dengan Nurani. Bandung: Humaniora Utama Press.

Sugiyono. (2017). Development and Research. Bandung: Alfabeta.

Suwardi, P. (2006). Seputar Bisnis dan Siaran Televisi (Pertama). Jakarta: TVRI Sumbar.

Syahputra, I. (2013). Rezim Media: Pergulatan Demokrasi, Jurnalisme, Infotainment Dalam Industri Televisi. Jakarta: PT Gramedia Pustaka Utama.

Nasrul Azwar, Pemerhati Media dan Budaya Sumatera Barat. Diakses pada Januari 2018. Sumber : http://mantagisme.blogspot.com/ 2007/09/sejarah-pers-sumbardialih-orang-lalu.html

Khairul Jasmi, Tokoh Pers dan Pemimpin Redaksi Koran Harian Singgalang. Diakses pada Januari 2018. Sumber http://www.khairuljasmi.com/201 1/03/pers-sumatra-barat.html

Rahmat Wahyudi, Kepala Perwakilan Koran Post Metro Kabupaten Pasaman, Wawancara Langsung, 20 Juli
2018.

Maryadi, Kepala Perwakilan Koran Harian Haluan Kabupaten Darmasraya, Wawancara Langsung, 4 Agustus 2018.

Irawadi, Pemimpin Koran Mingguan Zaman di Sumatera Barat, Wawancara Langsung, 7 Januari 2017.

Surya Andika, Kepala Perwakilan Koran Harian Haluan Kabupaten Pasaman Barat, Wawancara Langsung, 9 Januari 2017.

Risman, Kepala Perwakilan Koran Harian Haluan Kabupaten Solok, Wawancara Tidak Langsung, Januari 2014.

\section{Islamic Comunication Journal

